\title{
EFFECTS OF PONDEROSA PINE FOREST RESTORATION ON HABITAT FOR BATS
}

\author{
Shelly A. Johnson ${ }^{1,3}$ and Carol L. Chambers ${ }^{1,2}$
}

\begin{abstract}
Aвstract.-Ponderosa pine (Pinus ponderosa) forests in the southwestern United States, used by 16 species of bats, are managed with thinning and prescribed fire to restore tree densities and fire regimes to conditions that existed prior to Euro-American settlement. Using 2 approaches (roosting and foraging) to categorize forest habitat for bats, we evaluated how restoration treatments may affect habitat use. We hypothesized that more foraging activity would occur in thinned stands because more species are adapted to open forest, but that more roosts would occur in unthinned stands where snags were unaffected by mechanical treatments and prescribed fire. During the summers of 2006 and 2007, we used acoustic detectors to record call rates of bats as a measure of activity level and compared activity levels among stands that had undergone 3 thinning treatments (light, moderate, and heavy, with 245, 172, or 142 trees per hectare postthinning, respectively) and an unthinned stand as a control (1201 trees per hectare). With radiotelemetry, we located roosts used by reproductive females of 2 common species of forest-associated bats (long-eared myotis, Myotis evotis, and Arizona myotis, Myotis occultus) during summer 2007. We measured roost characteristics at 3 spatial scales (roost, microplot, and surrounding landscape) to contrast between roosts used by Myotis species and randomly selected comparison snags, microplots, and study area landscape. Among thinned and unthinned stands we did not detect a difference in activity levels for all bats $(P=$ $0.2)$, nor a difference in call rates for Myotis spp. $(P=0.1)$. However, there was lower activity $(P=0.01)$ for non-Myotis bats in unthinned compared to thinned stands. This is probably because most non-Myotis species are better adapted to foraging in open forests. Of 24 roosts for long-eared myotis and Arizona myotis, only $31 \%$ and $25 \%$, respectively, occurred in thinned stands. Bats selected large-diameter $(>68 \mathrm{~cm}$ diameter at breast height) ponderosa pine snags with exfoliating bark. Roosts for Arizona myotis were in areas with elements of old-growth structure, whereas roosts for long-eared myotis occurred in areas similar to stratified, midsuccessional, even-aged forest. Managing for large-diameter ponderosa pine snags and a variety of tree densities and age classes will provide roosting and foraging habitat for bats. We found no distinct "best" treatment to recommend overall, likely because of species differences, with some bats better adapted to opencanopy and some to closed-canopy forest. Maintaining diverse habitat will support a diverse bat assemblage.
\end{abstract}

Resumen.-Los bosques de pino ponderosa (Pinus ponderosa) en el suroeste de los Estados Unidos, utilizados por 16 especies de murciélagos, son manejados mediante incendios forestales prescritos y controlados para restaurar la densidad de árboles y los regímenes de incendios que existían con anterioridad al asentamiento euroamericano. Empleando dos estrategias (descanso y forrajeo) para clasificar el hábitat forestal de los murciélagos, evaluamos cómo los tratamientos de restauración afectan el uso del hábitat. Planteamos la hipótesis de que la actividad de forrajeo de los murciélagos sería mayor en sitios poco espesos, ya que más especies están adaptadas a bosques abiertos, mientras que la mayoría de los sitios de descanso se asentarían en sitios más espesos, donde los árboles muertos no fuesen afectados por tratamientos mecánicos ni por incendios prescritos. Durante el verano del 2006 y del 2007, utilizamos detectores acústicos para registrar las tasas de llamados de los murciélagos como medida del nivel de actividad y comparamos los niveles de actividad entre tres tratamientos de raleo (suave, moderado e intenso con 245, 172 o 142 árboles por hectárea [aph] post-raleo, respectivamente) y un control sin raleo (1201 aph). Durante el verano del 2007 localizamos, con la ayuda de radio telemetría, las áreas de descanso utilizadas por hembras reproductoras de dos especies comunes de murciélagos asociados al bosque (myotis de oreja larga, Myotis evotis y myotis de Arizona, Myotis occultus). Medimos las características de los sitios de descanso en tres escalas espaciales (descanso, microparcela y paisaje circundante) para contrastar entre las especies y los árboles muertos, las microparcelas y el paisaje, todos ellos elegidos aleatoriamente (comparación). No detectamos diferencias en los niveles de actividad de ningún murciélago entre los sitios espesos o no espesos $(P=0.2)$, ni diferencia alguna en las tasas de llamadas de los Myotis $(P=0.1)$. Sin embargo, detectamos menor actividad $(P=0.01)$ de los no-Myotis en los sitios espesos en comparación con los sitios no espesos. Ello se debe, probablemente, a que la mayoría de las especies no Myotis se adaptan mejor a forrajear en bosques abiertos. De 24 sitios de descanso de los myotis de orejas largas y de los myotis de Arizona, sólo el $31 \%$ y el $25 \%$ respectivamente, se encontraron en sitios poco espesos. Los murciélagos eligieron árboles longevos (pino ponderosa) de corteza exfoliante de gran diámetro ( $>68 \mathrm{~cm}$ de diámetro a la altura del pecho). Los sitios de descanso de los myotis de Arizona fueron en áreas con estructuras de crecimiento antiguas, mientras que los sitios de descanso de los myotis de oreja larga se hallaron en áreas similares a las de una sucesión intermedia estratificada, en bosques de igual edad. El óptimo control de los pinos ponderosa longevos de gran diámetro, usados como estructuras de reposo, y de la variedad de densidades de los árboles de diferentes edades, proporcionarán hábitats de reposo y forrajeo para los murciélagos. No encontramos un tratamiento distintivo "ideal" que recomendar en general, probablemente debido a las diferencias en las

\footnotetext{
${ }^{1}$ Box 15018, School of Forestry, Northern Arizona University, Flagstaff, AZ 86011.

${ }^{2}$ Corresponding author. E-mail: carol.chambers@nau.edu

3Present address: University of Florida, Department of Wildlife Ecology and Conservation, Gainesville, FL 32611.
} 
especies de murciélagos, donde algunos se adaptan mejor a los bosques de follajes abiertos y otros a los bosques de follajes cerrados. El mantener un hábitat diverso ayudará al ensamblaje de una gran diversidad de murciélagos.

Ponderosa pine (Pinus ponderosa) forests of the southwestern United States are adapted to a frequent fire regime that maintains a relatively open, uneven age structure (Cooper 1960, Minnich et al. 1995). With the exclusion of fire following Euro-American settlement in the late 1800s, these forests are now densely overgrown, fuel heavy, and vulnerable to catastrophic wildfires (Covington and Moore 1994, Covington et al. 1997, Fulé et al. 2012). To reduce fuel loads and the threat of wildfire, many areas are being restored to open, lowdensity (e.g., <150 trees per hectare [tph]) conditions similar to those that existed prior to Euro-American settlement, by use of thinning and prescribed fire (Cooper 1960, Covington and Moore 1994, Fulé et al. 1997, 2001). These forest management treatments can have substantial and immediate impacts on habitat for bats (e.g., changes in prey availability and accessibility through change in forest density and composition [Aldridge and Rautenbach 1987, Dodd et al. 2012], as well as loss of potential roosting structures through removal or change in surrounding forest structure [Ganey and Vojta 2005]).

Roosts and foraging habitat are key resources for bats (Barclay 1991, Lewis 1995, Vaughan 1997, Kunz and Lumsden 2003, Kusch and Schmitz 2013) that are especially important during reproductive periods when females give birth to and raise young. Maternity roosts are critical for reproduction because a suitable microclimate increases survival and development of young (Racey 1982, Kunz 1987, Zahn 1999). In northern Arizona, females of 16 species use ponderosa pine forests as roosting and foraging habitat (Table 1), wherein they give birth and raise pups during summer (Rabe et al. 1998, Solvesky and Chambers 2009, Saunders 2015). At least 7 of these species use cracks or exfoliating bark of large-diameter ponderosa pine snags as maternity roosts (Rabe et al. 1998, Morrell et al. 1999, Bernardos et al. 2004, Solvesky and Chambers 2009, Saunders 2015). Close proximity of maternity roosts to foraging areas allows reproductive females to conserve energy, since they are limited in the distance they can travel while tending pups (Lewis 1995, Henry et al. 2002).
All bats found in northern Arizona are insectivorous and acquire prey using strategies such as aerial pursuit or hover-gleaning (Hinman and Snow 2003; Table 1). Although bats can be variable in their use of these strategies, aerial pursuit is typically used by less maneuverable species (e.g., hoary bat, Lasiurus cinereus) and in areas of low clutter, such as open forests or clearings. Hovergleaning is used by more maneuverable species and in areas of high clutter, such as closed-canopy forests with dense vegetation (Aldridge and Rautenbach 1987, Norberg and Rayner 1987, Fenton 1990, Mancina et al. 2012). Forest management treatments (thinning and prescribed fire) change the amount of clutter by removing trees and snags (Thomas et al. 1979, Horton and Mannan 1988, McHugh and Kolb 2003), thereby altering foraging habitat and roosts for bats.

Because relatively little is known about the response of bats to forest management, we examined activity levels and located maternity roosts of bats in forests managed using restoration approaches. Our objectives were to determine differences in nightly bat activity (based on call rates) between thinned and unthinned stands during the summer reproductive season, and to describe characteristics of snag roosts selected by bats in this area. We expected higher levels of bat activity in thinned stands because tree densities in these stands were similar to pre-Euro-American settlement (Cooper 1960, Covington and Moore 1994, Covington et al. 1997). We predicted that density of large-diameter snags used as roosts would be higher in unthinned forest because the lack of disturbance from management operations would protect large snags. To evaluate the diversity of roost characteristics, we selected 2 focal species that represented different foraging strategies and the range of roost types in ponderosa pine forests, namely the Arizona myotis (Myotis occultus) and the long-eared myotis (Myotis evotis). Arizona myotis form large maternity colonies (up to 800 individuals), forage in lower-clutter environments over water and tree canopies, and select large-diameter snags as roosts (M.J. Rabe, Arizona Game and Fish Department, 


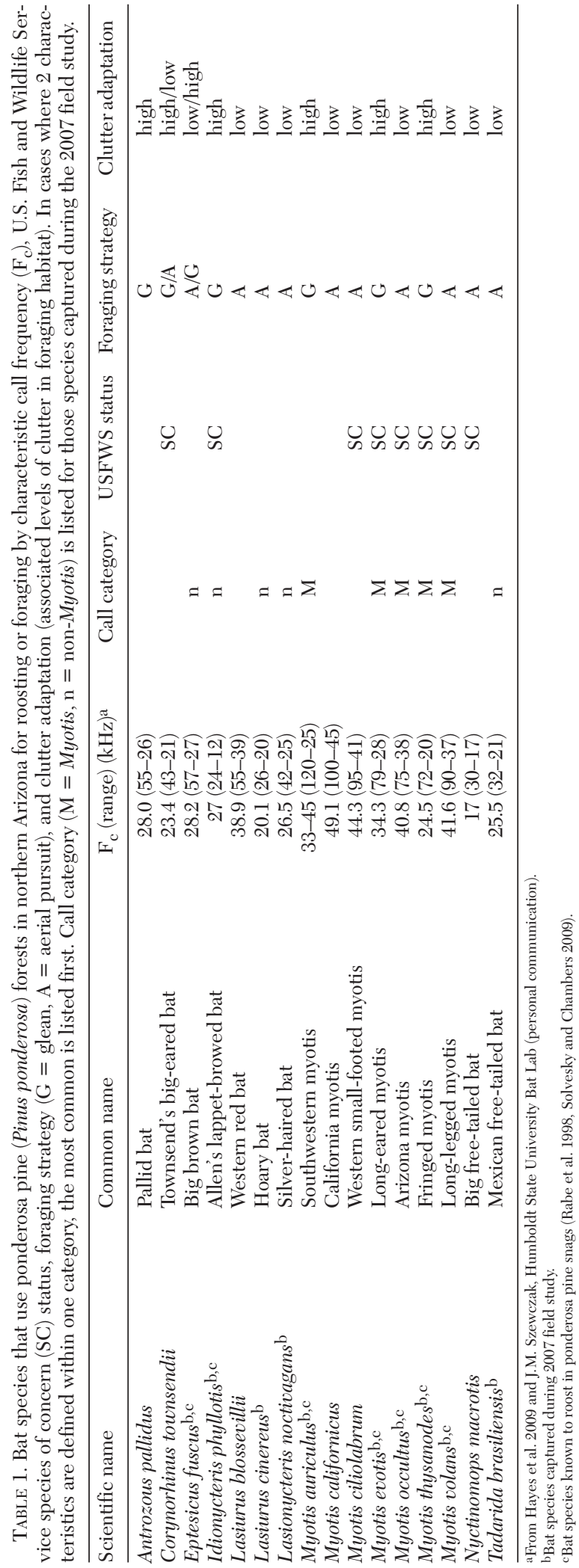


unpublished data; Saunders 2015). Longeared myotis are hovering gleaners adept at foraging in high clutter; they use a wider variety of roosts (e.g., snags, stumps, caves, sinkholes) but form smaller colony sizes $(<50$ individuals; Findley and Wilson 1982, Hill and Smith 1984, Hinman and Snow 2003).

\section{METHODS}

\section{Study Area}

We investigated habitat use by bats in a 6000 -ha study area centered on Fort Valley Experimental Forest (FVEF) on the Coconino National Forest in northern Arizona $\left(35^{\circ} 22^{\prime} \mathrm{N}\right.$, $\left.111^{\circ} 44^{\prime} \mathrm{W}\right)$. The area was dominated by ponderosa pine trees approximately 90 years old with a diameter at breast height $(\mathrm{dbh})<30 \mathrm{~cm}$ but also included small numbers $(\leq 5 \%)$ of Gambel oak (Quercus gambelii) below $2250 \mathrm{~m}$ and conifers (Abies spp. and Picea spp.) above $2400 \mathrm{~m}$; few cliffs or rock crevices existed in the area. Elevation ranged from 2160 to $2790 \mathrm{~m}$, slope from $0 \%$ to $29 \%$, and the dominant aspect was southwest. The area had a bimodal precipitation pattern with winter snowfall and summer monsoon rains. Mean summer temperature and precipitation was $17.5{ }^{\circ} \mathrm{C}$ and $8.9 \mathrm{~cm}$ in 2006 , and $17.2^{\circ} \mathrm{C}$ and $6.5 \mathrm{~cm}$ in 2007, respectively (Huebner 2006). Because fire (natural surface, prescribed, and wild) was excluded from 1876 to 2000 , tree densities were unusually high prior to forest restoration treatments.

Nightly activity was sampled within twelve 15-ha stands within the FVEF that had received forest restoration treatments (Fig. 1). Nine of the 12 FVEF stands were thinned between December 1998 and September 1999, and broadcast burns were conducted between winter 2000 and spring 2001 (Fulé et al. 2001, Skov et al. 2005). Three replicates of each thinning treatment were implemented by retaining either 1.5 to 3 (heavily thinned), 2 to 4 (moderately thinned), or 3 to 6 (lightly thinned) replacement trees for each evidence of a tree, stump, or snag that existed prior to Euro-American settlement. Because large dead presettlement trees must sometimes be replaced with small postsettlement trees, the number of replacement trees required per presettlement remnant varied depending on the size of suitable replacements $>40 \mathrm{~cm}$ dbh, and this variation resulted in a small degree of overlap between tree densities in some stands. Tree density was reduced from an average of 1195 tph (Skov et al. 2005) to 142 tph ( $\mathrm{SE}=$ 27 , range 115-169), 172 tph $(\mathrm{SE}=12$, range 160-184), and 245 tph ( $\mathrm{SE}=32$, range 213277) for heavy, moderate, and light thinning treatments, respectively. Untreated (unthinned and unburned) control stands with densities of 1201 tph $(\mathrm{SE}=311)$ were used for comparison. Treatments and controls were arranged in 3 blocks (FVEF blocks; Fig. 1).

\section{Nightly Activity}

We conducted passive acoustic surveys from July to August 2006 and May to August 2007 to compare activity levels (call rates) of bats among restoration-treated areas in FVEF. We used 4 Anabat II Bat Detectors and a zerocrossings analysis interface module (ZCAIM) with an incorporated timer (Titley Scientific, Brendale, Queensland, Australia) and remote transducers $(15 \times 30$-cm Plexiglas reflector plate with rubber microphone housing to protect the microphone from precipitation) to record calls. We placed microphones on a $45^{\circ}$ angle from horizontal against a tree bole at a height of $2 \mathrm{~m}$. In each stand, we designated 5 survey points (center, northeast, northwest, southeast, and southwest) $\geq 60 \mathrm{~m}$ from stand edges or other survey points. Because differences in vegetative clutter may affect echolocation calls (Patriquin and Barclay 2003), we placed the detectors in open patches $(>10$ to $20 \mathrm{~m}$ diameter) near each survey point to standardize the location of microphones among treatments and the detectability of bat calls. We tested the distance from which microphones detected bats with the Bat Chirp Board (Nevada Bat Technology, Las Vegas, Nevada, USA) and positioned detectors so they faced similar opening sizes. We sampled each block 14 times (6 in 2006 and 8 in 2007) with one detector in each treatment type per night. We randomized the sequence of blocks, order of sampling points, and assignment of detector for each point. Detectors recorded calls from sunset to sunrise in each sample night. We calibrated detectors with the Bat Chirp Board at the start and midpoint of each field season to ensure equal detection capability among detectors.

We reviewed all Anabat files with AnalookW (version 3.5e, Titley Scientific) software and eliminated files that did not contain sequences 


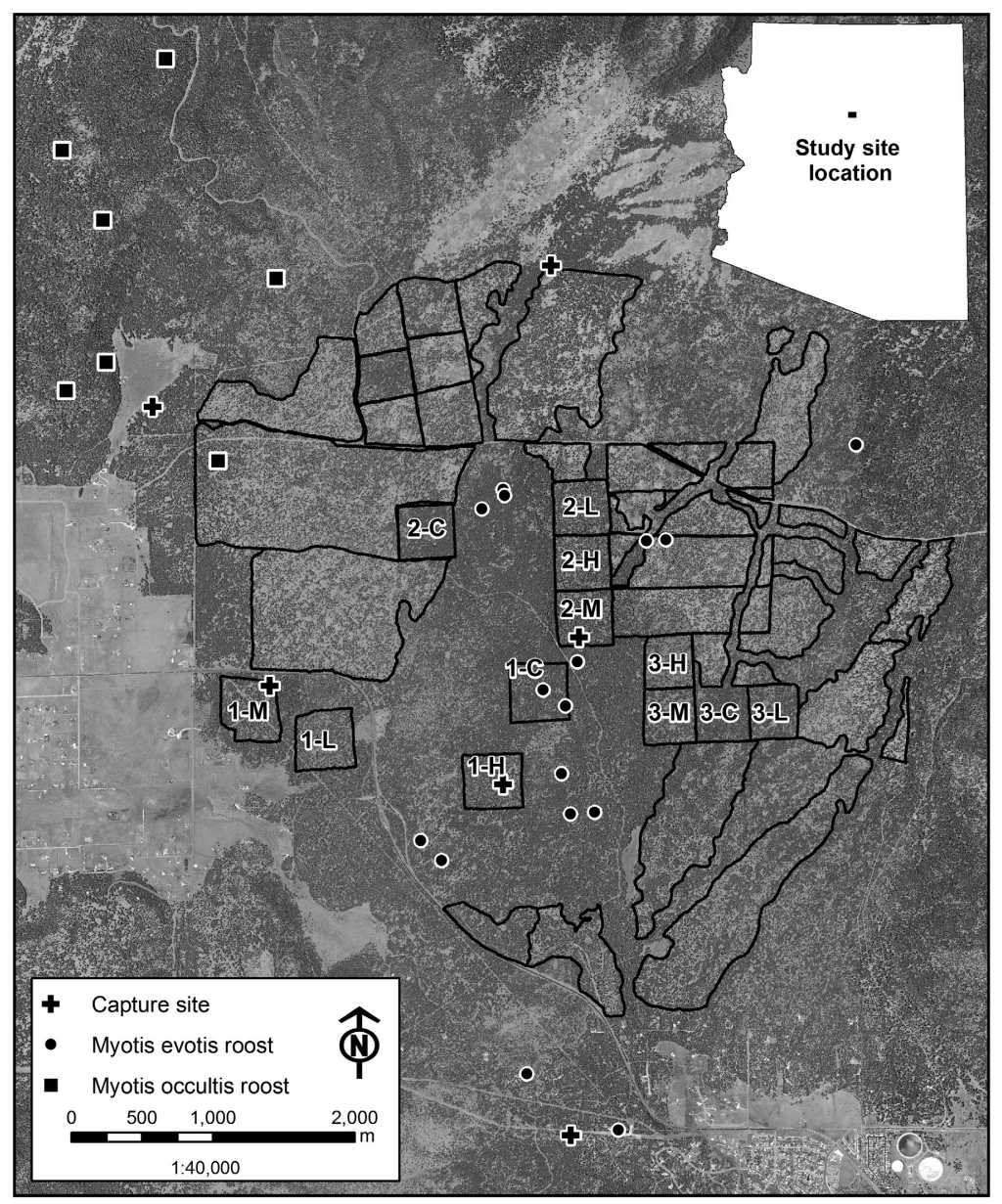

Fig. 1. Capture sites, roost locations for bats, and Fort Valley Experimental Forest (FVEF) restoration stands (outlined) used for acoustically monitoring nightly activity in a 6000-ha study area in northern Arizona. Blocks are indicated by 1,2 , or 3 ; $\mathrm{C}=$ control (unthinned); treatments include the following: $\mathrm{L}=$ lightly thinned, $\mathrm{M}=$ moderately thinned, and $\mathrm{H}=$ heavily thinned. We compared nightly activity in the FVEF stands during summers of 2006 and 2007 and located bat roosts throughout the study area.

of $\geq 5$ calls by bats or calls identifiable as bats. Because of the difficulty in distinguishing species by calls for many Myotis bats in the southwestern United States, we grouped bats into 2 categories to evaluate activity levels. Using a species list based on captures in the study area during summer 2007, we categorized bat calls as either Myotis or non-Myotis (Table 1; Crampton and Barclay 1998, Humes et al. 1999, Erickson and West 2003) using characteristic frequency $\left(\mathrm{F}_{\mathrm{c}}\right)$ and slope $\left(\mathrm{S}_{\mathrm{c}}\right)$ of calls (O’Farrell and Gannon 1999, Hayes et al. 2009; J.M. Szewczak, Humboldt State University Bat Lab, personal communication). We identified call sequences with $\mathrm{F}_{\mathrm{c}}>35 \mathrm{kHz}$ or with $\mathrm{S}_{\mathrm{c}}>150$ octaves per second (OPS) and calls of fringed myotis (Myotis thysanodes; which has an $\mathrm{F}_{\mathrm{c}}<30 \mathrm{kHz}$ but an $\mathrm{S}_{\mathrm{c}}>150$ OPS and is one of the few readily identifiable Myotis calls) as Myotis, and all other calls with $\mathrm{F}_{\mathrm{c}}<30 \mathrm{kHz}$ and $\mathrm{S}_{\mathrm{c}}<100$ OPS as non-Myotis (C. Corben, AnaBat Detector and AnaLook Software developer, personal communication). On a case-by-case basis we compared questionable sequences and those between 30 and $35 \mathrm{kHz}$ to an existing call library of bats in northern Arizona (O'Farrell and Gannon 1999). We calculated average call rate per hour by night for each stand for all calls, Myotis calls only, and non-Myotis calls only. 
We pooled data across summer months each year to represent the reproductive period for bats in the area (i.e., when pregnant females, nursing mothers, and volant young are present) and calculated an average call rate per stand for each summer. Surveys in 2006 may underrepresent activity of pregnant females because we started in July.

To test the null hypothesis that call rates did not differ between treatment types, we used a one-way ANOVA, with block and treatment as model effects and each block-year $(n$ $=6$ ) as a separate unit (Ott and Longnecker 2001). We treated years separately to account for potential differences between years; blockby-treatment interactions were accounted for by the blocking factor and placed in the error term of the model. Because the blocking design accounted for variation in nightly (e.g., temperature, humidity, rainfall) and withinseason (e.g., moon phase, insect blooms, pup volancy) factors across survey dates, we did not include these factors in analyses. We compared differences between means of each pair post hoc with Student's $t$ test using JMP 5.0.1.2 (SAS 2002). We set $\alpha=0.05$ for all analyses.

\section{Roost Locations}

To identify roosts, we captured bats over water throughout the 6000-ha study area using mist nets on 22 nights between 12 June and 16 July 2007 . We netted at 4 earthen water catchments, 4 water-filled plastic pools $(1.5 \mathrm{~m}$ diameter), and 1 artificial resin roost (Chambers et al. 2002) (Fig. 1). We opened nets 30 min after sunset and kept them open until we had captured at least 2 reproductive females of our focal species (long-eared myotis and Arizona myotis) or until $\geq 3 \mathrm{~h}$ had elapsed after sunset and capture rates had slowed to $<1$ bat per hour. We recorded species, sex, age (adult or juvenile based on the absence of cartilaginous epiphyseal plates in the phalanges of juveniles; Brunet-Rossinni and Wilkinson 2009), reproductive status, and weight (to the nearest $0.2 \mathrm{~g}$ ) for all bats captured. We determined reproductive status for females by palpation of the abdomen to determine pregnancy and examination of the mammary glands to determine lactation or postlactation. Capturing and handling of bats conformed to guidelines established by the American Society of Mammalogists (Kirkland et al. 1998) under a protocol approved by the
Northern Arizona University Institutional Animal Care and Use Committee.

We attached radio transmitters (LB-2N, Holohil Systems Ltd., Ontario, Canada) using nontoxic latex adhesive (Torbot Bonding Cement, Torbot Group Inc., Cranston, RI) to reproductive (pregnant or lactating) females of our focal species that weighed $\geq 7$ g. Radio transmitters weighed $\leq 5 \%$ of the individual's body mass (Aldridge and Brigham 1988). We limited the number of radio transmitters we deployed to 2 per species per night at each site to avoid oversampling bats that shared the same roosts. We released bats that were fitted with a radio transmitter at the capture site within $30 \mathrm{~min}$ and located roosts of radiotagged bats on a daily basis until the radio transmitter failed or dropped from the bat. We calculated distance between roosts and capture sites for each radio-tagged bat that we tracked. We tested for differences between focal species in travel distances between consecutive roosts using a Wilcoxon's signed-ranks test (JMP 5.0.1.2; SAS 2002). We conducted exit counts at roosts from $10 \mathrm{~min}$ prior to sunset until bats ceased emerging or for $\geq 30 \mathrm{~min}$ to confirm the use and location of roosts.

We measured characteristics of each roost and a randomly selected comparison snag. We selected comparison snags that were the same species as roost snags (ponderosa pine), that met a minimum size requirement for use by bats $(\geq 31.2 \mathrm{~cm} \mathrm{dbh}, \geq 3 \mathrm{~m}$ in height-dimensions based on snags used in our study and previous studies; Rabe et al. 1998, Morrell et al. 1999, Hinman and Snow 2003), and that were $>150 \mathrm{~m}$ from the roost, based on the minimum distance bats traveled between roosts (Vonhof and Barclay 1996). We chose the snag matching these criteria that was closest to a random point generated by a geographic information system (GIS; Rabe et al. 1998), then visually searched for signs of bats (presence of guano) to avoid selecting a snag that was used by bats. We measured the same variables at roosts and comparison snags: dbh, height of snag, top condition (intact or broken), and presence of exfoliating bark. We measured characteristics of the microplot surrounding each roost or comparison snag following methods of Rabe et al. (1998); we centered a 0.04 -ha (11.3-m radius) plot on the roost and measured the number of live trees by diameter, percent canopy cover (calculated using a 
spherical densiometer), and number of snags $\geq 1.4 \mathrm{~m}$ tall and $\geq 20 \mathrm{~cm} \mathrm{dbh}$. We treated each roost as an experimental unit and considered multiple roosts used by a single individual to be independent, because roost switching is common and roosts are usually used by multiple bats, indicating a simultaneous decision by multiple individuals (Lewis 1995, Vonhof and Gwilliam 2007). In addition, a 2-person survey team conducted a snag census by counting the number of snags $(\geq 31.2 \mathrm{~cm} \mathrm{dbh}, \geq 3 \mathrm{~m}$ in height) in a 1-ha plot centered on each roost. Surveyors counted snags by simultaneously walking $30 \mathrm{~m}$ apart.

To describe landscape characteristics surrounding roosts that bats selected, we calculated mean canopy cover within a 7.1-ha plot of the roost (150-m radius, based on the minimum distance bats traveled between roosts) and categorized percent canopy cover as $0 \%$ to $10 \%$ (meadows and forest clearings), $11 \%$ to $50 \%$ (open forest), and $51 \%$ to $100 \%$ (dense forest). We used a GIS (ArcGIS v9.2, Environmental Systems Research Institute, Redlands, CA) 30-m-resolution canopy cover raster layer developed from a Landsat image and digital elevation model. We categorized percent canopy cover within a $1613-\mathrm{m}$ radius (corresponding to the average distance from capture sites to roosts) around all sites where we captured bats $(n=6)$ for comparison. We derived elevation, aspect, and slope for each roost.

To compare snag densities among FVEF restoration treatments with those found near roosts, we censused snags on 15 ha in one heavily thinned stand (expected to have the greatest reduction in snag density because of mechanical treatments and prescribed burning) and one unthinned stand (expected to have the least reduction in snag density). We walked simultaneous transects in pairs spaced $60 \mathrm{~m}$ apart in one heavily thinned stand and $30 \mathrm{~m}$ apart in one unthinned stand to account for lower visibility. We calculated the number of large snags ( $\geq 31.2 \mathrm{~cm} \mathrm{dbh,} \geq 3 \mathrm{~m}$ in height) per hectare by treatment type (heavily thinned or unthinned) and noted snag recruitment or loss based on snags marked during a previous survey in 1999 (V. Alm and C. Chambers, unpublished data).

We determined which attributes predicted roost use by using contingency analysis for categorical measurements and single-variable logistic regression likelihood-ratio chi-square tests with receiver operating characteristic (ROC) curves for significant variables (Hosmer and Lemeshow 2000). The ROC value reports the probability that the variable accurately identifies a bat roost. A ROC value of 0.50 to $0.70,0.70$ to 0.90 , and $>0.90$ indicates low, moderate, and very high accuracy, respectively (Swets 1996). We used separate analyses for each focal species. We set $\alpha=0.05$ for all statistical analyses.

\section{RESUlts}

\section{Nightly Activity}

During 188 detector-nights, we collected 3313 audio files, some containing multiple bat calls. After discarding unusable files, we retained 1874 (57\%) files for analyses. From these files we identified 1969 bat calls, of which $45 \%$ were Myotis, $40 \%$ were non-Myotis, and 15\% could not be assigned to either group. We did not detect a difference in mean number of echolocation calls for all bats among treatments $\left(F_{3,5}=1.86, P=0.2\right.$; Fig. 2$)$ nor for Myotis spp. among treatments $\left(F_{3,5}=2.24, P=0.1\right)$. However, call rates of non-Myotis differed $\left(F_{3,5}=\right.$ $5.42, P=0.01)$, with fewer calls in unthinned compared to heavily thinned stands (Fig. 2). There were also higher call rates in unthinned stands for Myotis compared with non-Myotis $\left(F_{1,10}=49.6, P \leq 0.0001\right.$; Fig. 2$)$.

\section{Roost Locations}

We captured 55 long-eared myotis (32 female) and 29 Arizona myotis (17 female) and placed radio transmitters on 10 long-eared myotis and 8 Arizona myotis at 6 sites. We captured focal species at 3 locations within FVEF stands and 3 locations $\leq 2 \mathrm{~km}$ north, west, or south of FVEF. Most captures (85\%) and all roosts for long-eared myotis occurred in the eastern portion of the study area; $90 \%$ of captures and all roost locations for Arizona myotis were in the western portion of the study area (Fig. 1).

We tracked bats for an average of 5 days $(\mathrm{SE}=1$, range $1-11)$, locating 24 roosts: 16 roosts for long-eared myotis and 8 roosts for Arizona myotis (Fig. 1). Most roosts $(71 \%)$ were in unthinned areas; only 7 roosts occurred in thinned areas ( 5 and 2 roosts for long-eared myotis and Arizona myotis, respectively). Roosts for long-eared myotis were in ponderosa pine snags $(n=11)$, buildings $(n=2)$, 
$\square$ All calls $\square$ non-Myotis $\square$ Myotis

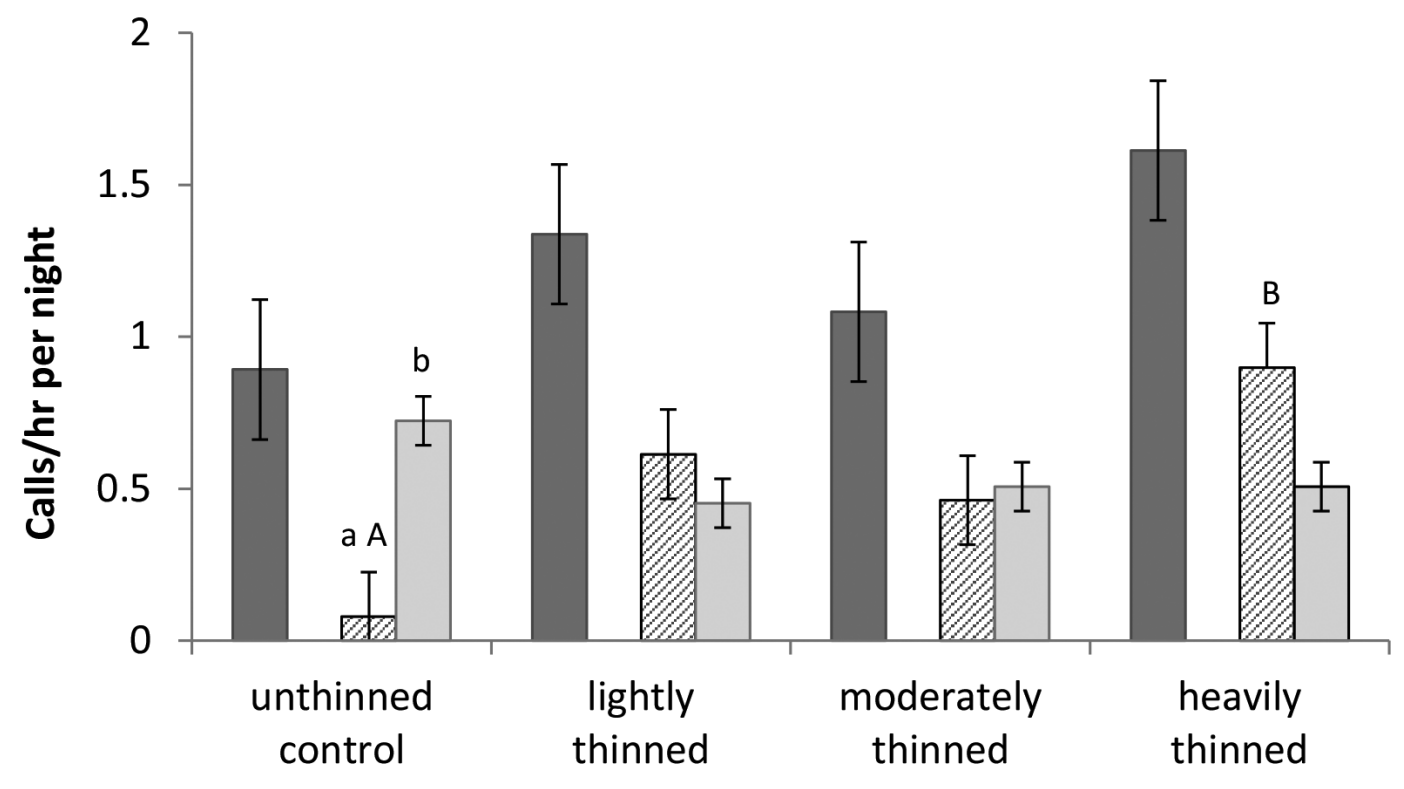

Fig. 2. Call rates of the entire bat assemblage (all calls), Myotis bats, and non-Myotis bats by stand type (unthinned control, lightly thinned, moderately thinned, and heavily thinned) in Fort Valley Experimental Forest, northern Arizona, from nightly activity surveys conducted in the summers of 2006 and 2007. For all calls, $P=0.22$ and SE is represented by the error bars. For Myotis and non-Myotis call rates, lowercase letters indicate differences between these groups in unthinned controls, and capital letters indicate differences within non-Myotis call rates between unthinned controls and heavily thinned stands. $P \leq 0.05$ indicates significance; standard error is represented by the error bars.

rock crevices $(n=2)$, and a live ponderosa pine tree (damaged and with exfoliating bark; $n=1)$. Arizona myotis roosts were in ponderosa pine snags $(n=6)$, a Douglas-fir (Pseudotsuga menziesii) snag $(n=1)$, and an artificial bark roost on a snag $(n=1)$. We conducted exit counts at 17 of the 24 roosts and found 5 bats $(\mathrm{SE}=3$, range 1-16) at 12 longeared myotis roosts and 17 bats $(\mathrm{SE}=4$, range 1-39) bats at 5 Arizona myotis roosts. Exit counts confirmed that roosts in snags and trees were beneath exfoliating bark.

Snag roosts used by both species had larger dbh (long-eared myotis: $\mathrm{ROC}=0.73$; Arizona myotis: $\mathrm{ROC}=0.96$; Table 2), higher frequency of broken tops (long-eared myotis: roosts $=81 \%$, comparison snags $=29 \%, P=$ 0.02 ; Arizona myotis: roosts $=71 \%$, comparison snags $=37 \%, P=0.04$ ), and more frequent presence of loose bark (for both species, $73 \%$ of snags with loose bark, $22 \%$ of comparison snags with loose bark; $P=0.001$ ) than comparison snags. Roosts for Arizona myotis had higher numbers of excavated $(\mathrm{ROC}=1.0)$ and natural cavities $(\mathrm{ROC}=0.85)$ and were surrounded by higher snag densities $(\mathrm{ROC}=0.82)$ than comparison snags (Table 2).

Both species used an average of 1.8 roosts per individual $(\mathrm{SE}=0.2$, range $1-3)$ and moved $860 \mathrm{~m}(\mathrm{SE}=256$, range 155-2860) when switching roosts. Arizona myotis moved greater distances $(n=5 ; 1737 \mathrm{~m}, \mathrm{SE}=319)$ between consecutive roosts than long-eared myotis $(n=7 ; 234 \mathrm{~m}, \mathrm{SE}=28 \mathrm{~m} ; Z=8.1$, $P=0.004)$, and mean distance from capture site to roost was $1613 \mathrm{~m}(\mathrm{SE}=280$, range $338-4227 \mathrm{~m}$ ). Although only 3 roosts were found within FVEF stands (2 long-eared myotis roosts in unthinned control stands and 1 Arizona myotis roost in a moderately thinned stand), 5 roosts occurred in areas thinned within the last 5 years. The remaining roosts were in areas that had not been recently treated and exhibited a wide range of tree densities (Fig. 3). On average, the landscape surrounding roosts of long-eared myotis was characteristically denser forest (51\%-100\% canopy cover, $\mathrm{ROC}=0.81)$ than random comparison, and neither species used areas with low canopy cover for roost sites ( $0 \%-10 \%$ canopy cover) 


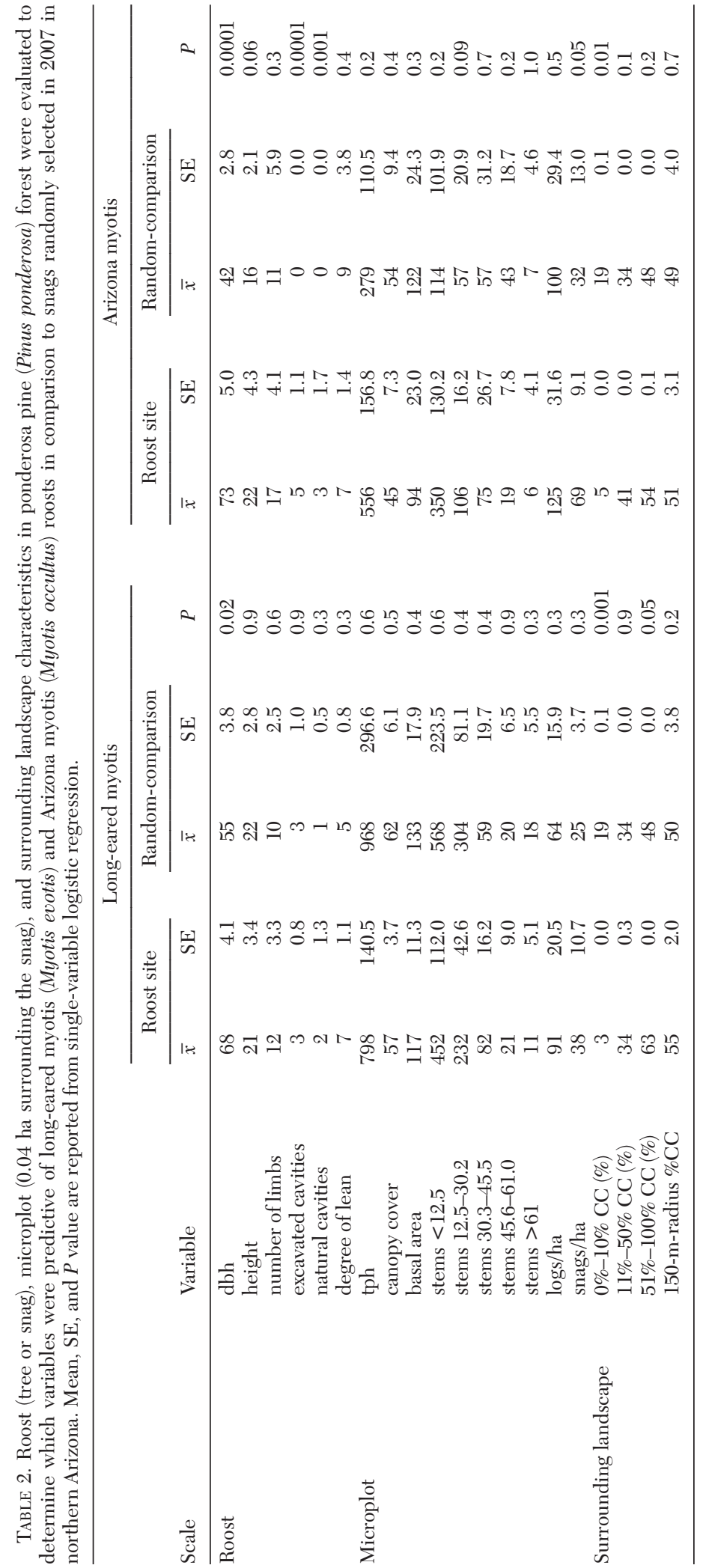




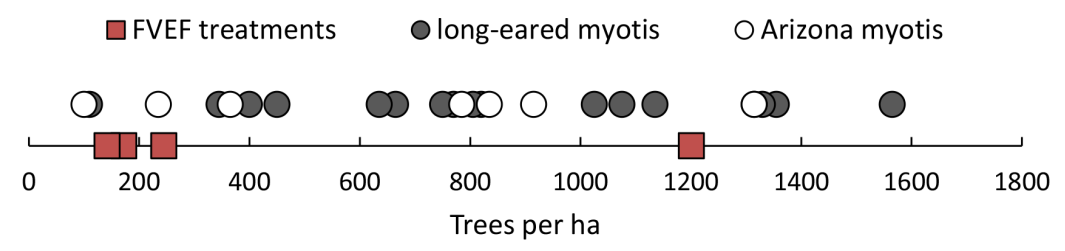

Fig. 3. Live tree density (trees per hectare estimated based on 11.3-m-radius plot) for roosts of long-eared myotis and Arizona myotis compared to published tree density for Fort Valley Experimental Forest (FVEF) forest restoration treatments.

(long-eared myotis: ROC $=0.94 ;$ Arizona myotis: $\mathrm{ROC}=0.90$; Table 2 ).

The snag census in the FVEF treatments found more snags $\geq 31.2 \mathrm{~cm} \mathrm{dbh}$, a size that bats were likely to use for roosting, in the thinned FVEF stands (thinned $=8.0$ snags $/$ ha, unthinned $=5.6$ snags/ha). New snags $\geq 31.2$ $\mathrm{cm} \mathrm{dbh}$ were recruited in both thinned and unthinned stands $(37 \%$ and $144 \%$ recruitment, respectively).

\section{Discussion}

\section{Bat Habitat Use}

Using 2 approaches to categorize forest habitat for bats, we found no distinct "best" treatment to recommend, likely because some bat species are better adapted to open-canopy and some to closed-canopy forest. Bats used both thinned and unthinned forest for roosting, commuting, and foraging habitat.

Differences in nightly bat activity levels among treatment types may be attributed to species differences in morphology, maneuverability, and detectability (Aldridge and Rautenbach 1987, O’Farrell and Gannon 1999, Kingston et al. 2000). Bats can use large areas for foraging (e.g., maximum areas of 30 to 3000 ha, a range based on 13 studies; Lacki et al. 2007) and can travel long distances (e.g., $1.5 \mathrm{~km}$, an average based on 15 studies; Lacki et al. 2007) to forage or obtain water, thus potentially traveling through multiple stands in an evening (Clark 1993, de Jong 1995). Bats adapted to open forest environments will travel through low-clutter areas, and those adapted to dense forest will travel through high-clutter areas as they attempt to feed throughout the night (Verboom and Spoelstra 1999, Schnitzler and Kalko 2001). We hypothesized higher activity in thinned stands compared to unthinned controls. The only difference we detected was for the non-Myotis group, species with lower maneuverability and thus better adaptation to low-clutter environments such as thinned forests. The Myotis group used thinned and unthinned stands because bats adapted to both open and dense forest comprised this group.

Foraging and roosting are intrinsically linked. Accessibility between roosting sites and foraging areas is an important factor in roost site selection (Brigham 1991, Waldien et al. 2000). Captures took place at open water sources in early to midevening. Bats likely visited water sources soon after emergence to drink at sites relatively close to roost sites (Kunz and Kurta 1988). Thus, we assume that capture locations were a reflection of, rather than a bias in, where roosts were located. Availability and locations of roosts are often the focus of bat habitat studies and can differ between species (e.g., Kunz 1982, Lewis 1995, Vonhof and Barclay 1996, Rabe et al. 1998, Henry et al. 2002). Although we captured bats throughout the 6000-ha study area, each species used spatially distinct regions for roosting, with the Arizona myotis roosts in an area of more open forest on generally steeper slopes and the long-eared myotis roosts in a more closed-canopy forest area.

The Arizona myotis demonstrated more specialization in its roost selection than the long-eared myotis. Snag roosts occurred in areas with high snag density relative to surrounding areas and were similar to roosts identified for this species by Saunders (2015). Specialization was also demonstrated by the farther distance to capture site from roost and higher roost fidelity by the species as a whole; almost half of the radio-collared bats were found in the same roost as previously identified by another Arizona myotis tracked during the study. Arizona myotis were found only in snags and the artificial resin roost (which simulated exfoliating bark and was located on a snag; Chambers et al. 2002), also suggesting less flexibility in selection of 
roosting structures. In contrast, the longeared myotis roosted in a variety of structures (snags, trees, buildings, and rock crevices), with no bats roosting in the same location used by another bat tracked during the study.

Seven of the 10 species that we captured are known to roost in ponderosa pine snags in northern Arizona (Rabe et al. 1998, Bernardos et al. 2004, Solvesky and Chambers 2009). The characteristics of roosts in snags were similar between species in this study and reconfirm the findings of previous studies, with bats selecting ponderosa pine snags with large $\mathrm{dbh}$ and decay (e.g., loose bark; Brigham et al. 1997, Rabe et al. 1998, Solvesky and Chambers 2009, Saunders 2015). Larger snags may provide more space under exfoliating bark needed to create a suitable microclimate for maternity colonies. The artificial roost in this study is one example of a smaller snag ( $\mathrm{dbh}=$ $46 \mathrm{~cm}$ versus $69 \mathrm{~cm}$ to $89 \mathrm{~cm}$ for other roost snags used by Arizona myotis) used as a roost, possibly because the artificial roost created a large exfoliating bark structure similar to those on larger snags (Chambers et al. 2002). Other snag characteristics were likely correlated with the overall decay class of the snag and presence of exfoliating bark (Thomas et al. 1979).

\section{Habitat Management}

It is important to provide a forest structure that will allow for development of suitable roosting snags while providing a mosaic of forest structures suitable for species with different flight adaptations. When thinning dense, untreated areas, resource managers should retain or create large-diameter ponderosa pine snags for roosting structures. Although we counted more large snags in thinned stands (Johnson 2008), higher recruitment in unthinned stands is likely due to increased mortality in densely forested areas as a result of drought, disease outbreak, and suppression (Smith 1986). Prescribed fire and windthrow in the thinned stands may remove existing snags without recruiting equal numbers of replacements (Randall-Parker and Miller 2002, Chambers and Mast 2005, Ganey and Vojta 2005). Protecting (e.g., raking away debris and litter) and monitoring snags during prescribed fire to reduce snag mortality, retaining mature ponderosa pine during thinning operations, or using live, mature trees to create snags (Walter and Maguire 2005) is critical. Educating personnel trained in prescribed fire implementation and management about the habitat provided by snags can also protect this important habitat element. When snags appropriate for roosting are not available, resource managers can temporarily supplement natural roosts with artificial roosts (Chambers et al. 2002, Mering and Chambers 2012, 2014).

Heterogeneity in forest structure and tree density within forest treatment areas will promote roosting and foraging habitat for a diversity of bats. Live tree densities around roosts in our study were between the densities of unthinned and heavily thinned restoration stands (Fig. 3). We suspect that neither extreme provided ideal habitat, but that FVEF stands may represent a dominant forest density that existed in ponderosa pine prior to Euro-American settlement (Cooper 1960, Covington and Moore 1994), to which bats in this forest are adapted. Past management recommendations for wildlife (e.g., Reynolds et al. 1992) have suggested retaining approximately 5 to 7 snags per hectare, one group of 3 to 5 mature ponderosa pine trees per hectare in openings $>0.4 \mathrm{ha}$, small forest openings between 0.2 and $1.6 \mathrm{ha}$, and a diversity in forest structures from young saplings to old growth arranged in clusters. Based on our study, these recommendations are still a generally appropriate forest structure for bat habitat, especially if large-scale treatments with thinning and prescribed fire, such as those demonstrated in FVEF, are conducted throughout southwestern ponderosa pine forests where a diverse bat assemblage resides.

All habitat managers should understand the adaptations of the bat assemblage in their region and how differences in these adaptations may affect habitat selection. While patterns of bat habitat use identified in this study may be generally useful to guide management actions elsewhere, specific management implications from this study should be applied primarily to ponderosa pine forests in the Southwest. Use of multiple techniques (e.g., mist netting, radiotelemetry, and acoustic detection) can aid in developing forest management recommendations which address both use and availability of roosting sites and foraging areas for the species assemblage under consideration. 


\section{ACKNOWLEDGMENTS}

We are grateful for field assistance from L. Farrow, C. Schmidt, and volunteers. Funding for this project was provided by Arizona Game and Fish Department's Urban Wildlife/ Urban Wildlife Habitat Heritage Fund. This research was also supported, in part, by McIntire-Stennis appropriations to Northern Arizona University and the state of Arizona, and the U.S. Forest Service, Coconino National Forest. We thank S.S. Rosenstock, T.C. Theimer, J.L. Ganey, and 2 anonymous reviewers for their helpful comments on earlier drafts.

\section{Literature Cited}

AldRidge, H.D., AND R.A. BRigham. 1988. Load carrying and maneuverability in an insectivorous bat: a test of the $5 \%$ "rule" of radio telemetry. Journal of Mammalogy 69:379-382.

Aldridge, H.D., and L.L. Rautenbach. 1987. Morphology, echolocation, and resource partitioning in insectivorous bats. Journal of Animal Ecology 56: 763-778.

BarCLaY, R.M.R. 1991. Population structure of temperate zone insectivorous bats in relation to foraging behaviour and energy demand. Journal of Animal Ecology 60:165-178.

Bernardos, D.A., C.L. Chambers, and M.J. Rabe. 2004 Selection of Gambel oak roosts by southwestern myotis in ponderosa pine-dominated forests, northern Arizona. Journal of Wildlife Management 68: $595-601$.

Brigham, R.M. 1991. Flexibility in foraging and roosting behaviour by the big brown bat (Eptesicus fuscus). Canadian Journal of Zoology 69:117-121.

Brigham, R.M., R.M. Vonhof, R.M.R. Barclay, and J.C. GWILLIAM. 1997. Roosting behavior and roost-site preferences of forest-dwelling California bats (Myotis californicus). Journal of Mammalogy 78:1231-1239.

Brunet-Rossinni, A.K., And G.S. Wilkinson. 2009. Methods for age estimation and the study of senescence in bats. Pages 315-325 in T.H. Kunz and S. Parsons, editors, Ecological and behavioral methods for the study of bats. Johns Hopkins University Press, Baltimore, MD.

Chambers, C.L., V. Alm, M.S. Siders, and M.J. Rabe. 2002. Use of artificial roosts by forest-dwelling bats in northern Arizona. Wildlife Society Bulletin 30: 1085-1091.

Chambers, C.L., And J.N. Mast. 2005. Ponderosa pine snag dynamics and cavity excavation following wildfire in northern Arizona. Forest Ecology and Management 216:227-240.

Clark, B.S., D.M. Leslie Jr., and T.S. Carter. 1993. Foraging activity of adult female Ozark big-eared bats (Plecotus townsendii ingens) in summer. Journal of Mammalogy 74:422-427.

CoOPER, C.F. 1960. Changes in vegetation, structure, and growth of southwestern pine forests since white settlement. Ecological Monographs 30:129-164.
Covington, W.W., P.S. Fulé, M.M. Moore, S.C. Hart, T.E. Kolb, J.N. Mast, S.S. SACKETT, and M.R. WAGNER. 1997. Restoring ecosystem health in ponderosa pine forests of the Southwest. Journal of Forestry 95:23-29.

Covington, W.W., And M.M. Moore. 1994. Southwestern ponderosa forest structure: changes since EuroAmerican settlement. Journal of Forestry 92:39-47.

Crampton, L.H., AND R.M.R. BarCLAY. 1998. Selection of roosting and foraging habitat by bats in differentaged aspen mixedwood stands. Conservation Biology 12:1347-1358.

DE JoNG, J. 1995. Habitat use and species richness of bats in a patchy landscape. Acta Theriologica 40:237-248.

Dodd, L.E., M.J. Lacki, E.R. Britzke, D.A. Buehler, P.D. Keyser, J.L. Larkin, A.D. Rodewald, T.B. Wigley, P.B. Wood, AND L.K. Rieske. 2012. Forest structure affects trophic linkages: how silviculture disturbance impacts bats and their insect prey. Forest Ecology and Management 267:262-270.

ERICKSON, J.L., AND S.D. WeST. 2003. Associations of bats with local structure and landscape features of forested stands in western Oregon and Washington. Biological Conservation 109:95-102.

Fenton, M.B. 1990. The foraging behaviour and ecology of animal-eating bats. Canadian Journal of Zoology 68:411-422.

Findley, J.S., AND D.E. WiLson. 1982. Ecological significance of chiropteran morphology. Pages 243-260 in T.H. Kunz, editor, Ecology of bats, Plenum Publishing Corporation, New York, NY.

Fulé, P.Z., W.W. Covington, And M.M. Moore. 1997. Determining reference conditions for ecosystem management of southwestern ponderosa pine forests. Ecological Applications 7:895-908.

Fulé, P.Z., J.E. Crouse, J.P. Roccaforte, and E.L. KALIES. 2012. Do thinning and/or burning treatments in western USA ponderosa or Jeffrey pine-dominated forest help restore natural fire behavior? Forest Ecology and Management 269:68-81.

Fulé, P.Z., C. MCHugh, T.A. Heinlein, And W.W. CovINGTON. 2001. Potential fire behavior is reduced following forest restoration treatments. Pages 28-35 in R.K. Vance, C.B. Edminster, B. Carleton, W.W. Covington, and J.A. Blake, editors, Ponderosa pine ecosystems restoration and conservation: steps toward stewardship. Proceedings RMRS-P-22, Rocky Mountain Research Station, USDA Forest Service, Ogden, UT.

GANEY, J.L., AND S.C. VOJTA. 2005. Changes in snag populations in northern Arizona mixed-conifer and ponderosa pine forests, 1997-2002. Forest Science 51:396-405.

Hayes, M.A., K.W. Navo, L.R. Bonewell, C.J. Mosch, AND R.A. ADAMs. 2009. Allen's big-eared bat (Idionycteris phyllotis) documented in Colorado based on recordings of its distinctive echolocation call. Southwestern Naturalist 54:499-501.

Henry, M., D.W. Thomas, R. Vaudry, and M. Carrier. 2002. Foraging distances and home range of pregnant and lactating little brown bats (Myotis lucifugus). Journal of Mammalogy 83:767-774.

HiLl, J.E., AND J.D. SMITH. 1984. Bats: a natural history. Cambridge University Press, Cambridge, United Kingdom.

Hinman, K.E., AND T.K. SNOw. 2003. Arizona Bat Conservation Strategic Plan. Technical Report 213, Nongame 
and Endangered Wildlife Program, Arizona Game and Fish Department, Phoenix, AZ.

Horton, S.P., and R.W. Mannan. 1988. Effects of prescribed fire on snags and cavity-nesting birds in southeastern Arizona pine forests. Wildlife Society Bulletin 16:37-44.

Hosmer, D.W., And S. Lemeshow. 2000. Applied logistic regression. 2nd edition. John Wiley \& Sons, Inc. New York, NY.

Huebner, D.P. 2006. Fort Valley Experimental Forest 30-minute meteorological data: 2003-present. U.S. Department of Agriculture, Forest Service, Rocky Mountain Research Station, Fort Collins, CO; [accessed 3 April 2008]. http://www.fs.fed.us/rm/ data_archive/dataaccess/FortValleyEF_30min meteorology.html

Humes, M.L., J.P. Hayes, and M.W. Collopy. 1999. Bat activity in thinned, unthinned, and old-growth forests of western Oregon. Journal of Wildlife Management 63:553-561.

Johnson, S.A. 2008. Effects of ponderosa pine forest restoration on bat habitat in northern Arizona. Master's thesis, Northern Arizona University, Flagstaff.

Kingston, T., G. Jones, A. Zubaid, And T.H. Kunz. 2000 Resource partitioning in rhinoploid bats revisited. Oecologia 124:332-342.

Kirkland, G.L., Jr., and the Animal Care and Use Committee of the American Society of MamMALOGISTS. 1998. Guidelines for the capture, handling, and care of mammals as approved by the American Society of Mammalogists. Journal of Mammalogy 79:1416-1431.

KunZ, T.H. 1982. Roosting ecology of bats. Pages 1-55 in T.H. Kunz, editor, Ecology of bats. Plenum Press, New York, NY.

KunZ, T.H. 1987. Post-natal growth and energetics of suckling bats. Pages 395-420 in M.B. Fenton, P.A. Racey, and J.M.V. Rayner, editors, Recent advances in the study of bats. Cambridge University Press, Cambridge, United Kingdom.

KunZ, T.H., AND A. KurTa. 1988. Capture methods and holding devices. Pages 1-28 in T.H. Kunz, editor, Ecological and behavioral methods for the study of bats. Smithsonian Institution Press, Washington, DC.

KunZ, T.H., AND L.F. LumsDen. 2003. Ecology of cavity and foliage roosting bats. Pages 3-89 in T.H. Kunz and M.B. Fenton, editors, Bat ecology. University of Chicago Press, Chicago, IL

Kusch, J., AND A. Schmitz. 2013. Environmental factors affecting the differential use of foraging habitat by three sympatric species of Pipistrellus. Acta Chiropterologica 15:57-67.

Lacki, M.J., J.P. Hayes, and A. Kurta. 2007. Bats in forests: conservation and management. Johns Hopkins University Press, Baltimore, MD.

LEWIS, S.E. 1995. Roost fidelity of bats: a review. Journal of Mammalogy 76:481-496.

Mancina, C.A., L. García-Rivera, and B.W. Miller. 2012. Wing morphology, echolocation, and resource partitioning in syntopic Cuban mormoopid bats. Journal of Mammalogy 93:1308-1317.

McHugh, C.W., And T.E. Kolb. 2003. Ponderosa pine mortality following fire in northern Arizona. International Journal of Wildland Fire 12:7-22.

Mering, E.D., And C.L. Chambers. 2012. Artificial roosts for tree-roosting bats in northern Arizona. Wildlife Society Bulletin 36:765-772
Mering, E.D., And C.L. Chambers. 2014. Thinking outside the box: a review of artificial roosts for bats. Wildlife Society Bulletin 38:741-751.

Minnich, R.A., M.G. Barbour, J.H. Burk, and R.F. FerNAU. 1995. Sixty years of change in Californian conifer forests of the San Bernadino Mountains. Conservation Biology 9:902-914.

Morrell, T.E., M.J. Rabe, J.C. DeVos Jr., H. Green, and C.R. Miller. 1999. Bats captured in two ponderosa pine habitats in north-central Arizona. Southwestern Naturalist 44:501-506.

Norberg, U.M., and J.M. Rayner. 1987. Ecological morphology and flight in bats (Mammalia; Chiroptera): wing adaptations, flight performance, foraging strategy and echolocation. Philosophical Transactions of the Royal Society B: Biological Sciences 316:335-427.

O'Farrell, M.J., and W.L. Gannon. 1999. A comparison of acoustic versus capture techniques for the inventory of bats. Journal of Mammalogy 80:24-30.

OTT, R.L., AND M. LONGNECKER. 2001. An introduction to statistical methods and data analysis. 5th edition. Duxbury Press, Pacific Grove, CA.

Patriquin, K.J., AND R.M.R. Barclay. 2003. Foraging by bats in cleared, thinned and unharvested boreal forest. Journal of Applied Ecology 40:646-657.

Rabe, M.J., T.E. Morrell, H. Green, J.C. DeVos JR., AND C.R. Miller. 1998. Characteristics of ponderosa pine snag roosts used by reproductive bats in northern Arizona. Journal of Wildlife Management 62:612-621.

RaceY, P.A. 1982. Ecology of bat reproduction. Pages 57-104 in T.H. Kunz, editor, Ecology of bats. Plenum, New York, NY.

Randall-Parker, T., and R. Miller. 2002. Effects of prescribed fire in ponderosa pine on key wildlife habitat components: preliminary results and a method for monitoring. USDA Forest Service General Technical Report PSW-GTR-181.

Reynolds, R.T., T.T. GRaham, M.H. Reiser, R.T. Bassett, P.L Kennedy, D.A. Boyce JR., G. Goodwin, R. Smith, AND E.L. Fisher. 1992. Management recommendations for the Northern Goshawk in the southwestern United States. USDA Forest Service General Technical Report RM217.

[SAS] SAS Institute, Inc. 2002. JMP user's guide. SAS Institute, Inc., Cary, NC.

SAunders, E.H. 2015. Bat assemblage and selection of maternity roosts in a post-wildfire landscape. Master's thesis, Northern Arizona University, Flagstaff, AZ.

SChNitZler, H.U., and E.K.V. KaLKo. 2001. Echolocation by insect-eating bats. BioScience 51:557-569.

Skov, K.R., T.E. KolB, AND K.F. WALLin. 2005. Difference in radial growth response to restoration thinning and burning treatments between young and old ponderosa pine in Arizona. Western Journal of Applied Forestry 20:36-43.

SMITH, D.M. 1986. The practice of silviculture, 9th edition. John Wiley \& Sons, New York, NY.

Solvesky, B.G., and C.L. Chambers. 2009. Roosts of Allen's lappet-browed bat in northern Arizona. Journal of Wildlife Management 73:677-682.

SwETS, J.A. 1996. Signal detection theory and ROC analysis in psychology and diagnostics: collected papers. Lawrence Erlbaum Associates, Inc., Mahwah, NJ. 308 pp.

Thomas, J.W., R.G. Anderson, C. Maser, and E.L. Bull. 1979. Snags. Pages 60-77 in J.W. Thomas, editor, 
Wildlife habitats in managed forests: the Blue Mountains of Oregon and Washington, Agriculture Handbook No. 553, USDA Forest Service.

Vaughan, N. 1997. The diets of British bats (Chiroptera). Mammal Review 27:77-94.

Verboom, B., and K. Spoelstra. 1999. Effects of food abundance and wind on the use of tree lines by an insectivorous bat, Pipistrellus pipistrellus. Canadian Journal of Zoology 77:1393-1401.

Vonhof, M.J., and R.M.R Barclay. 1996. Roost-site selection and roosting ecology of forest-dwelling bats in southern British Columbia. Canadian Journal of Zoology 74:1797-1805.

Vonhof, M.J., and J.C. Gwilliam. 2007. Intra- and interspecific patterns of day roost selection by three species of forest-dwelling bats in southern British
Columbia. Forest Ecology and Management 252: $165-175$.

Waldien, D.L., J.P. Hayes, and E.B. Arnett. 2000. Dayroosts of female long-eared myotis in western Oregon. Journal of Wildlife Management 64:785-796.

Walter, S.T., AND C.C. Maguire. 2005. Snags, cavitynesting birds, and silvicultural treatments in western Oregon. Journal of Wildlife Management 69: 1578-1591.

ZAHN, A. 1999. Reproductive success, colony size and roost temperature in attic-dwelling bats Myotis myotis. Journal of Zoology 247:275-280.

Received 26 May 2016 Accepted 15 June 2017 Published online 16 October 2017 